\title{
Epstein-Barr virus-specific methylation of human genes in gastric cancer cells
}

\author{
Julie L Ryan ${ }^{1}$, Richard J Jones ${ }^{2}$, Shannon C Kenney ${ }^{3}$, Ashley G Rivenbark ${ }^{4}$, Weihua Tang ${ }^{4}$, Elizabeth RW Knight ${ }^{4}$, \\ William B Coleman ${ }^{4}$, Margaret L Gulley ${ }^{4^{*}}$
}

\begin{abstract}
Background: Epstein-Barr Virus (EBV) is found in 10\% of all gastric adenocarcinomas but its role in tumor development and maintenance remains unclear. The objective of this study was to examine EBV-mediated dysregulation of cellular factors implicated in gastric carcinogenesis.
\end{abstract}

Methods: Gene expression patterns were examined in EBV-negative and EBV-positive AGS gastric epithelial cells using a low density microarray, reverse transcription PCR, histochemical stains, and methylation-specific DNA sequencing. Expression of PTGS2 (COX2) was measured in AGS cells and in primary gastric adenocarcinoma tissues.

Results: In array studies, nearly half of the 96 human genes tested, representing 15 different cancer-related signal transduction pathways, were dysregulated after EBV infection. Reverse transcription PCR confirmed significant impact on factors having diverse functions such as cell cycle regulation (IGFBP3, CDKN2A, CCND1, HSP70, ID2, ID4), DNA repair (BRCA1, TFF1), cell adhesion (ICAM1), inflammation (COX2), and angiogenesis (HIF1A). Demethylation using 5-aza-2'-deoxycytidine reversed the EBV-mediated dysregulation for all 11 genes listed here. For some promoter sequences, CpG island methylation and demethylation occurred in an EBV-specific pattern as shown by bisulfite DNA sequencing. Immunohistochemistry was less sensitive than was western blot for detecting downregulation of COX2 upon EBV infection. Virus-related dysregulation of COX2 levels in vitro was not recapitulated in vivo among naturally infected gastric cancer tissues.

Conclusions: EBV alters human gene expression in ways that could contribute to the unique pathobiology of virus-associated cancer. Furthermore, the frequency and reversability of methylation-related transcriptional alterations suggest that demethylating agents have therapeutic potential for managing EBV-related carcinoma.

\section{Background}

Gastric cancer is the fourth most common type of cancer and the second leading cause of cancer death worldwide [1]. A variety of genetic alterations as well as infectious and other environmental agents appear to be factors in gastric carcinogenesis. Epstein-Barr virus (EBV), a double-stranded DNA gammaherpesvirus, is found within the malignant cells in $10 \%$ of gastric adenocarcinomas, and infection seems to precede malignant transformation [2]. Basic and clinical observations suggest that EBV-associated gastric cancers have a different pathobiology from EBV-negative gastric cancers [3-8].

\footnotetext{
* Correspondence: margaret_gulley@med.unc.edu

${ }^{4}$ Department of Pathology and Laboratory Medicine and the Lineberger Comprehensive Cancer Center, University of North Carolina, Chapel Hill, NC 27599-7525, USA

Full list of author information is available at the end of the article
}

Rational design of virus-directed therapy requires a better understanding of the pathogenic role of EBV in gastric carcinogenesis.

Prior studies have shown loss of three critical tumor suppressor gene products, CDH1 (E-cadherin), p73, and CDKN2A (p16), in EBV-infected gastric cancers [9-18]. Virus-associated methylation of these genes, along with evidence of global DNA methylation in EBV-positive cancers, suggests that EBV-related gastric cancers are a subset of $\mathrm{CpG}$ island methylator phenotype (CIMP) cancers [4,11,19-26]. A potential mediator is DNA methyltransferase 1 (DNMT1) that is upregulated in naturally infected gastric cancers and could help establish methylation patterns propagated to daughter cells upon cell division [21,27-29]. Ongoing studies are aimed at understanding the role of EBV and Helicobacter pylori infection in causing 
inflammation and associated global hypermethylation during gastric cancer development [22].

In cell line models, DNMT1 overexpression is mediated by EBV LMP1 and LMP2 [21,28-31]. EBV seems to employ epigenetic mechanisms to control the host transcriptome and also to control expression of its own virally encoded genes $[11,12,14,15,19,21$, $24,29,32,33]$. Upon initial infection of a cell, the unmethylated viral genome can undergo viral replication with new virion production, while a subset of infected cells acquire a highly methylated viral genome that squelches expression of foreign proteins and mediates long-term viral persistence by way of latent infection $[23,34]$. Infected tumors tend to have highly methylated EBV DNA, and methylation-related silencing of viral genes helps explain how infected tumors evade immune destruction.

While methylation of gene promoters is typically associated with transcriptional downregulation via selective binding of repressor proteins, the first protein ever shown to bind and activate a methylated promoter was EBV BZLF1, the key factor controlling the switch from latent to replicative forms of viral infection [35]. It appears that the virus has cleverly evolved a means of overcoming promoter methylation to its advantage $[34,35]$. Antiviral strategies are being explored for their antineoplastic potential. Interestingly, the most commonly used antiviral agents, acyclovir and ganciclovir, are effective at shutting down viral replication but they do not eliminate expression of latent and early lytic viral genes such as LMP1, LMP2 and BZLF1.

The clinical implications of EBV-related methylation of the gastric cancer genome are immense. First, emerging evidence shows the potential for improved diagnosis of gastric cancer by testing gastric washes for cancer-specific methylation patterns, perhaps in concert with tests for EBV to identify the virus-infected subset of cancers [36-40]. Differing patterns of promoter methylation in virus-positive compared to virus-negative cells $[11,21,24]$ emphasize the need to characterize methylation patterns in a manner that that maximizes assay sensitivity for cancer detection. Both infection and altered DNA methylation appear to be early events in carcinogenesis $[2,41]$, potentially facilitating detection of precancerous lesions in stomach juice.

A second clinical implication is the potential for improved treatment of gastric cancer using drugs that reverse the effect of promoter hypermethylation $[42,43]$. In particular, demethylating agents that inhibit DNA methyltransferase and reverse tumor suppressor gene silencing or oncogene activation are potential antineoplastic strategies [43]. Consideration must be given to possible differences in the effect of demethylating agents in virus-positive versus virus-negative tumors [43-45].
We and others have shown that naturally infected gastric cancers have lower CDKN2A (p16) expression $[14,15]$. In a clinical trial of fluorouracil (5FU) for gastric cancer, CDKN2A promoter methylation status was an independent predictor of survival [46]. The rationale for using demethylating agents like 5-aza-2'-deoxycytidine in clinical trials rests on scientific evidence that demethylating therapy modifies the tumorigenic properties of cancer cells.

Several investigators have successfully infected epithelial cell lines with EBV in vitro $[47,48]$. In the current study, EBV-positive and EBV-negative AGS gastric cancer cells were examined for differences in gene expression patterns using low-density microarray analysis and reverse transcription polymerase chain reaction (rtPCR). AGS is a cell line that was originally grown from gastric adenocarcinoma tissue and now is widely used as a model of gastric cancer. The role of DNA methylation in mediating selected effects was examined by bisulfite DNA sequencing and by testing the ability of a demethylating agent to reverse the effect of EBV on gene silencing. Results revealed extensive gene dysregulation upon EBV infection in AGS cells with evidence that promoter methylation is responsible, at least in part. Reversal of virus-associated transcriptional effects suggests that demethylating agents should be explored for their potential to control growth of EBV-related malignancies.

\section{Methods}

\section{Gastric Cancer Cell Lines}

The AGS gastric cancer cell line (ATCC CRL-1739) was cultured in Dulbecco's Modified Eagle's Medium containing $10 \%$ fetal bovine serum (heat-inactivated for 20 minutes at $\left.65^{\circ} \mathrm{C}\right)$ and $1 \%$ penicillin-streptomycin $(10,000$ units penicillin, 10,000 $\mathrm{\mu g} / \mathrm{ml}$ streptomycin, Gibco, Carlsbad, CA). The cells were infected with a recombinant EBV strain (a gift from Dr. Henri J. Delecluse) $[33,49,50]$ that was engineered to express green fluorescence protein (GFP) and hygromycin B resistance by cloning these genes into the prototypic B95.8 strain of EBV where the second copy of oriLyt normally resides. Before infection, AGS cells were transfected with $1 \mu \mathrm{g}$ of an expression vector encoding CD21 (the EBV receptor) and a puromycin resistance gene by using Fugene 6 (Roche, Indianapolis, IN) as previously described [51]. At 48 hours post-transfection, cells containing CD21 were positively selected for using $0.5 \mu \mathrm{g} / \mathrm{mL}$ of puromycin- $\mathrm{HCl}$ (Roche). Viral stocks of recombinant EBV were generated in kidney 293 cells, a human embryonic epithelial cell line, by inducing lytic replication using 20 $\mathrm{ng} / \mathrm{mL}$ phorbol 12-tetradecanoate 13-acetate and $3 \mathrm{mM}$ butyrate. Supernatants were harvested 3 days after induction, filtered $(0.8 \mu \mathrm{M})$, and frozen at $-80^{\circ} \mathrm{C}$ until 
use. Puromycin-resistant AGS cells were plated at 50\% of full density in 60-mm tissue culture dishes and coincubated with $1 \mathrm{~mL}$ of stock virions. Four days later, the EBV-infected AGS cells (now called AGS-B95HygB) were positively selected with $100 \mu \mathrm{g} / \mathrm{mL}$ hygromycin B (Roche).

DNA fingerprinting confirmed that AGS cells used in this study matched the genotype of AGS cells in the American Type Culture Collection. Fingerprinting was done using the PowerPlex 1.2 STR kit (Promega) followed by electrophoresis on an ABI 310 capillary gel electrophoresis instrument (Applied Biosystems).

\section{Gene Expression by Histochemical Stains}

Paraffin blocks were prepared from AGS and AGS-B95HygB cell lines, and paraffin blocks of primary gastric adenocarcinoma were retrieved from clinical archives. The residual clinical specimens represent all available EBV positive gastric cancers $(n=9)$ and a random selection of EBV-negative gastric cancers $(n=9)$. Histochemical stains were applied to paraffin sections to confirm infection and to evaluate gene expression. To prepare blocks, cultured cells were first rinsed in Dulbecco's phosphate buffered saline (Gibco, Invitrogen), harvested with $0.25 \%$ trypsin (Gibco, Invitrogen), enmeshed in a clot using Dade $\mathrm{Ci}$-Trol Coagulation Control (Citrated)-Level 1 (Dade Behring, Marburg, Germany) and Thrombin 200 (Pacific Hemostasis, Middletown, VA), fixed in $10 \%$ buffered formalin, embedded in paraffin, and sectioned onto coated slides.

$E B E R$ in situ hybridization was performed using fluorescein-labeled $E B E R$ probe and oligo(d)T control probe on a Benchmark in situ hybridization system (Ventana Medical Systems, Tucson, AZ). Immunohistochemical stains for EBV LMP1 and LMP2 proteins were performed as previously described [52] using citrate antigen retrieval and the CS1-4 cocktail of mouse monoclonal antibodies against LMP1 (1:100, Dako, Capinteria, CA) and the E411 rat monoclonal antibody against LMP2 (1 $\mathrm{mg} / \mathrm{ml}$, Asencion, Munich, Germany). Paraffin sections of EBV-related Hodgkin lymphoma and post-transplant lymphoproliferative disorder served as positive controls.

Immunohistochemical analysis of the EBV replicative proteins BMRF1 and BZLF1 was performed using antiBMRF1 clone G3-E31 (1:200 dilution, Research Diagnostics, Inc., Flanders, NJ) and anti-BZLF1 clone BZ.1 (1:25 dilution, Dako, Carpinteria, CA), while human PTGS2 (colloquially named cyclooxygenase-2, COX2) was assayed using anti-COX2 monoclonal antibody (1:200 dilution, Cayman Chemical). Sections were incubated with primary antibody for 30 minutes at $37^{\circ} \mathrm{C}$ for the EBV targets, or at $4^{\circ} \mathrm{C}$ overnight for COX2, using the blocking and detection protocols in the Super-Sensitive Non Biotin HRP Detection Kit (Biogenex). Bound antibody was detected using diaminobenzidine chromogen (Biogenex) and cells were counterstained with hematoxylin (Dako). Paraffin sections of oral hairy leukoplakia served as a positive control for lytic EBV, while reactive tonsil and nasopharyngeal carcinoma tissues served as controls for COX2 stains. Results were interpreted by microscopic scoring of malignant cells in $\geq 10$ fields at 400x magnification yielding an average proportion score $(0=$ none, $1=<1 \%, 2=1-10 \%, 3=10-33 \%$, $4=33-66 \%, 5=>66 \%$ of cells) and intensity score $(0=$ none, 1 = weak, 2 = intermediate, 3 = strong staining). Total scores were compared in EBV positive versus negative tumors using a Mann-Whitney unpaired $t$ test.

\section{Detection of the EBV genome}

A battery of quantitative real-time PCR (Q-PCR) assays targeting six disparate regions of the EBV genome was used to demonstrate that viral infection of AGS cells was successful. Amplified products were detected using the ABI Prism 7500 Real-Time PCR instrument with Sequence Detection System software (Applied Biosystems) as previously described using primers targeting the BamH1W, EBNA1, LMP1, LMP2, and BZLF1 regions of the EBV genome [52] or EBER1 DNA [53]. To check for amplicon contamination, every run contained at least two "no template" controls in which nuclease-free $\mathrm{H} 2 \mathrm{O}$ was substituted for template.

\section{Low-Density cDNA Microarray Analysis}

RNA was isolated from AGS and AGS-B95-HygB cells using the RNeasy RNA Mini Kit (Qiagen) after first using the QiaShredder ${ }^{\text {TM }}$ spin column (Qiagen) to lyse the cells. After confirming RNA integrity using an Agilent Bioanalyzer, expression microarray analysis was performed by SABiosciences Corporation (Frederick, MD) using their GEArray Q Series Human Signal Transduction in Cancer Gene Array. This low-density microarray consists of 96 probes that test activation of 15 signal transduction pathways involved in oncogenesis. (Target transcripts are listed in Results.) Biotin-labeled cDNA prepared from $10 \mu \mathrm{g}$ of each RNA sample using the AmpoLabeling-LPR method (SABiosciences) was hybridized to the array, and chemiluminescent detection was performed using a CCD camera. Integrated raw intensity values for each spot were generated by GEArray Analysis Suite software (SABiosciences), and further analysis and normalization was performed using Microsoft Excel. The lowest spot intensity value on each array was considered to be background and was subtracted from each raw intensity value for each probe, and then spot intensities were normalized to that of the housekeeping gene, glyceraldehydephosphate dehydrogenase (GAPDH). A pairwise comparison of gene expression levels was made between the EBV-positive cells (AGS-B95-HygB) and 
parental EBV-negative AGS cells. If the ratio was $\geq 2$ or $\leq 0.5$, the gene was considered to be upregulated or downregulated in infected cells.

\section{SYBR Green Semiquantitative rtPCR}

To confirm selected microarray gene expression results, rtPCR was performed using Real-Time $\mathrm{RT}^{2}$ gene-specific PCR primers (SABiosciences). The ReactionReady ${ }^{\mathrm{TM}}$ First Strand cDNA Synthesis Kit (SABiosciences) was used to convert $3 \mu \mathrm{g}$ of RNA to cDNA, and the cDNA was diluted 1:10 before PCR analysis. The following 38 cDNAs were targeted: GAPDH, $A 2 M, A B C B 1, B C L 2 L 1$, BIRC1, BIRC2, BIRC3, EN1, GADD45, HIF1A, ID2, IGFBP3, BRCA1, TMEPAI, IRF1, BCL2, BMP4, CDKN2A (p16), FN1, HK1, ICAM1, IL2, CCND1, MDM2, COX2 (PTGS2), TFRC, WISP1, TRAF1, CDK2, VCAM1, CDKN2C (p18), CDKN1A (p21), DUSP1, HSP70, NFKB1, TNFSF10, TRIM25, and FOSL1. Reactions were performed in a total volume of $25 \mu \mathrm{L}$ containing 1X TaqMan ${ }^{\circledR}$ Universal Mix (ABI), $\mathrm{RT}^{2}$ gene-specific primer set $\operatorname{mix}(10 \mu \mathrm{M}$ each primer, SABiosciences), $2.5 \mu \mathrm{L}$ 5X SYBR green solution (Molecular Probes, Eugene, OR), and $5 \mu \mathrm{L}$ of cDNA template. Thermocycling conditions were: $50^{\circ} \mathrm{C}$ for 2 minutes, $95^{\circ}$ $\mathrm{C}$ for 10 minutes, and 40 cycles of $95^{\circ} \mathrm{C}$ for 15 seconds and $60^{\circ} \mathrm{C}$ for 1 minute on an ABI 7500 instrument with Sequence Detection System software (Applied Biosystems). The same threshold was used for each gene and plate evaluated by the "Relative Quantification Plate" protocol. Each PCR reaction was run in triplicate for each sample on two separate 96-well plates, and results were averaged to determine relative differences in each gene's expression level in the EBV-positive versus EBVnegative cell line.

\section{Minor Groove Binding Probe Semiquantitative rtPCR}

To evaluate expression of five selected genes that were not on the microarray described above, semi-quantitative rtPCR assays were performed (Assays-on Demand, Applied Biosystems) using minor groove binding probes targeting helicase-like transcription factor $(H L T F)$, trefoil factor-1 (TFF1), basic-leucine zipper ATF-like transcription factor $(B A T F)$, inhibitor of DNA binding protein-4 (ID4), and nucleostemin $(N U)$. These five were selected because they are reportedly dysregulated in a substantial proportion of gastric adenocarcinomas or EBV-related cancers [32,54-59]. GAPDH served as an endogenous control for relative quantification purposes. RNA was converted to cDNA using the High Capacity cDNA Archive Kit (Applied Biosystems), and the cDNA was diluted 1:10 with nuclease-free water. Each $50 \mu \mathrm{L}$ PCR reaction contained: $1 \mathrm{X}$ TaqMan ${ }^{\circledR}$ Universal Master Mix, $1 \mathrm{X}$ Target Gene Expression assay or GAPDH Endogenous Control mix, and $10 \mu \mathrm{L}$ cDNA. To check for amplicon contamination, every expression assay on every plate contained at least two "no template" controls in which nuclease-free water was substituted for template. Thermocycling conditions and data analysis were as described above for the SYBR Green rtPCR.

\section{Demethylation Treatment and Sequencing of Bisulfite- modified DNA}

To study the effect of demethylation, the AGS and AGS-B95-HygB gastric cancer cell lines were grown to $75 \%$ confluency and then for three consecutive days 1 $\mu \mathrm{M}$ of fresh 5-aza-2'-deoxycytidine (5aza; Sigma) was added daily. On the fourth day, RNA and DNA were harvested from treated and untreated cultures. RNA was evaluated for gene expression levels, and DNA was examined for methylation after sodium bisulfite treatment (EZ DNA Methylation Kit, Zymo Research, Orange, CA) to convert unmethylated cytosines to uracil, while keeping methylated cytosines unchanged [60]. The positive control was CpGenome Universal Methylated DNA (Chemicon) subjected to the same bisulfite conversion, and control primers targeting the C8orf4 cellular gene promoter confirmed successful bisulfite conversion of each DNA sample [61]. CpG islands were identified using CpG Plot for each of five human genesICAM1 (RefSeq\# NM_00201), CDKN2A (p16) (RefSeq\# NM_000077.3), ID4 (RefSeq\# NM_001546), COX2 (RefSeq\# NM_000963), and TFF1 (RefSeq\# 003225.2)for which promoter sequences (3000 basepairs upstream of the transcription start site through exon 1) were downloaded from GenBank. The following parameters for $\mathrm{CpG}$ island identification were used: minimum length of $200 \mathrm{bp}$, minimum average percentage of $\mathrm{C}+\mathrm{G}$ of $50 \%$, and minimum average ratio of observed to expected $\mathrm{C}+\mathrm{G}$ of 0.6 [62]. To identify $\mathrm{CpG}$ dense regions for $C O X 2$ and $T F F 1$, the minimum length parameter was reduced to $50 \mathrm{bp}$ [61]. Primer sequences are shown in Table 1 . Each $50 \mu \mathrm{l}$ PCR reaction contained: 1X PCR Buffer, $2 \mathrm{mM} \mathrm{MgCl}_{2}, 1$ unit Platinum Taq DNA Polymerase (Invitrogen, Carlsbad CA), $0.2 \mathrm{mM}$ dNTPs (ABI), and 30 pmol of each primer. Thermocycling conditions were: $94^{\circ} \mathrm{C}$ for 2 minutes, 40 cycles of $94^{\circ} \mathrm{C}$ for 30 seconds, $55^{\circ} \mathrm{C}$ for 30 seconds, and $72^{\circ} \mathrm{C}$ for 1 minute, $72^{\circ} \mathrm{C}$ for 10 minutes. To monitor amplicon contamination, every run contained a "no template" control in which nuclease-free water was substituted for template

Sequencing was performed on amplicons of bisulfitetreated templates to identify the methylated and unmethylated CpGs with or without 5aza treatment. First, each PCR product was cloned into pGEM-T vector using the pGEM-T Easy Vector System II (Promega) and transformed in JM109 high efficiency competent cells. White colonies containing inserts were selected 


\begin{tabular}{|c|c|c|}
\hline \multirow[t]{3}{*}{ ICAM1 } & Forward & 5'-TGG GGG TTG TGG TTT TAG TT-3' \\
\hline & Reverse & $5^{\prime}-\mathrm{CTC}$ CCT CCA CTA AAA AC-3' \\
\hline & $\begin{array}{l}\text { Amplicon } \\
\text { size }\end{array}$ & $412 \mathrm{bp}$ \\
\hline \multirow{3}{*}{$\begin{array}{l}\text { CDKN2A } \\
\text { (p16) }\end{array}$} & Forward & 5'-AGA TGT TाT GTG GTT GTT GTG A-3' \\
\hline & Reverse & $5^{\prime}$-CAA AAA TCT TCC ATT CTT CAA AC-3' \\
\hline & $\begin{array}{l}\text { Amplicon } \\
\text { size }\end{array}$ & $418 \mathrm{bp}$ \\
\hline \multirow[t]{3}{*}{ ID4 } & Forward & $\begin{array}{l}5^{\prime}-T T T \text { TT GGG TAT ATA TTA GTT TGG- } \\
3^{\prime}\end{array}$ \\
\hline & Reverse & 5'-TAT CCT AAT CAC TCC CTT C-3' \\
\hline & $\begin{array}{l}\text { Amplicon } \\
\text { size }\end{array}$ & $477 \mathrm{bp}$ \\
\hline \multirow[t]{3}{*}{$\operatorname{cox} 2$} & Forward & 5'-TAT GTG TTG TAT ATA GAG TAG A-3' \\
\hline & Reverse & 5'-AAA AAA TAA TCC CCA CTC TC - $3^{\prime}$ \\
\hline & $\begin{array}{l}\text { Amplicon } \\
\text { size }\end{array}$ & $399 \mathrm{bp}$ \\
\hline \multirow[t]{3}{*}{ TFF1 } & Forward & 5'-TTA GGT TGG AGT GTA GTA GG-3' \\
\hline & Reverse & 5'-CCT ACT CAT ATC TAA AAA ACC C-3' \\
\hline & $\begin{array}{l}\text { Amplicon } \\
\text { size }\end{array}$ & $489 \mathrm{bp}$ \\
\hline \multirow[t]{3}{*}{$\begin{array}{l}\text { C8orf4 } \\
\text { control }\end{array}$} & Forward & $\begin{array}{l}\text { 5'-GAA TTA AAA TAT AAG GAG AGT } \\
\text { TाT-3' }\end{array}$ \\
\hline & Reverse & $\begin{array}{l}5^{\prime}-A A C \text { ATT ACC CAA ACA TAA AAC AA- } \\
3^{\prime}\end{array}$ \\
\hline & $\begin{array}{l}\text { Amplicon } \\
\text { size }\end{array}$ & $328 \mathrm{bp}$ \\
\hline
\end{tabular}

and cultured overnight, and plasmid DNA was extracted using the QiaPrep Spin Miniprep Kit (Qiagen). Sequencing was done on an ABI 3100 Genetic Analyzer using the ABI PRISM ${ }^{\mathrm{mm}}$ BigDye $^{\mathrm{Tm}}$ Version 1.1 Terminator Cycle Ready Reaction Kit with AmpliTaq DNA Polymerase and an M13R3 primer. Results were downloaded into Sequencher software (Gene Codes, Ann Arbor, MI) to obtain the reverse compliment of each sequence, and both forward and reverse sequences were aligned and analyzed to distinguish unmethylated cytosines from methylated cytosines.

\section{Western Blot on the AGS cell line}

Because of the potential for COX2 inhibitor therapy to overcome COX2 effects, the RNA-based results for COX2 were chosen for follow-up study at the proteinlevel. Confluent AGS cells with or without EBV were harvested with $0.25 \%$ trypsin, washed twice in phosphate-buffered saline, and pelleted by centrifugation. Cells were resuspended in $500 \mathrm{ul} \mathrm{NP}-40$ cell lysis buffer (50 mM Tris- $\mathrm{HCl}, 150 \mathrm{mM} \mathrm{NaCl}, 1 \% \mathrm{NP}-40, \mathrm{pH} 8.0$ ), incubated on ice for 30 minutes, and spun at 12,000 $\mathrm{rpm}$ for 15 minutes at $4{ }^{\circ} \mathrm{C}$. Aliquots of lysate (at 50 , 100,150 ug protein per well) were resolved using SDSPAGE on a tris-glycine 4-20\% gradient gel (Invitrogen) and transferred onto a nitrocellulose membrane. COX2 was detected with a 1:5,000 dilution of the monoclonal antibody followed a 1:10,000 dilution of secondary antibody conjugated with alkaline phosphatase (Amersham Biosciences), and visualization with a Typhoon PhosphorImager (Molecular Dynamics). Band density measured semi-quantitatively and normalized to beta actin (ACTB) was compared between infected and uninfected AGS cells.

\section{Results}

\section{EBV Infection of AGS Gastric Cancer Cells}

Successful EBV infection of AGS gastric cancer cells was confirmed using six Q-PCR assays targeting disparate segments of the EBV genome. EBER in situ hybridization showed no EBER expression in the parental "EBV-negative" AGS cells, whereas greater than $90 \%$ of AGS-B95-HygB cells were EBER-positive and had activated-appearing nuclear morphology (Figure 1). The proliferation rate was increased as shown by confluence of cultured AGS-B95-HygB cells three days prior to parental AGS cells. The infection persisted for at least 4 months as shown by GFP and EBER histochemical stains. EBV latent (LMP1 and LMP2A) and lytic (BZLF1 and BMRF1) proteins were not expressed in uninfected AGS cells, whereas $\sim 10 \%$ of infected cells expressed LMP1, half the cells expressed LMP2A, and $~ 35 \%$ expressed BMRF1 and BZLF1 proteins implying active viral replication (Figure 1).

\section{Cellular Gene Expression Differences in EBV-positive versus EBV-negative AGS Cells}

Expression levels of 96 cellular genes were analyzed in AGS and AGS-B95-HygB cells using low density microarray analysis with chemiluminescent detection (Figure 2). After normalization to GAPDH, pairwise comparison of gene expression levels between the EBV-positive and EBV-negative AGS cells revealed that of the 96 genes on the microarray, 43 were dysregulated at least two-fold after EBV infection. Surprisingly, an EBV-associated increase in expression was observed for only 6 genes (IGFBP3, GADD45, IRF1, Grp78/HSPB1, GLUT1/ SLC2A1, TMEPAI), while decreased expression was observed for the remaining 37 dysregulated genes (ABCB1,BCL2L1, BIRC2,BMP2, CDKN2A, DUSP1, HIF1A,ICAM1, ID2, NFKB1, COX2, TFRC, VCAM1, WISP1, TRIM25, IL2, BMP4, MDM2, CCND1, CDK2, BAX, p57, p19, CSN2, CXCL9, IL4, JUN, KLK3, LTA, MMP7, PPARG, TNFRSF1OB, WIG1, WNT2, PTCH2).

SYBR Green rtPCR was used to check the microarray findings for 26 of the dysregulated genes and for 12 additional genes in which no significant change was observed on the microarray. Greater than two-fold alteration in mRNA level in infected versus uninfected 


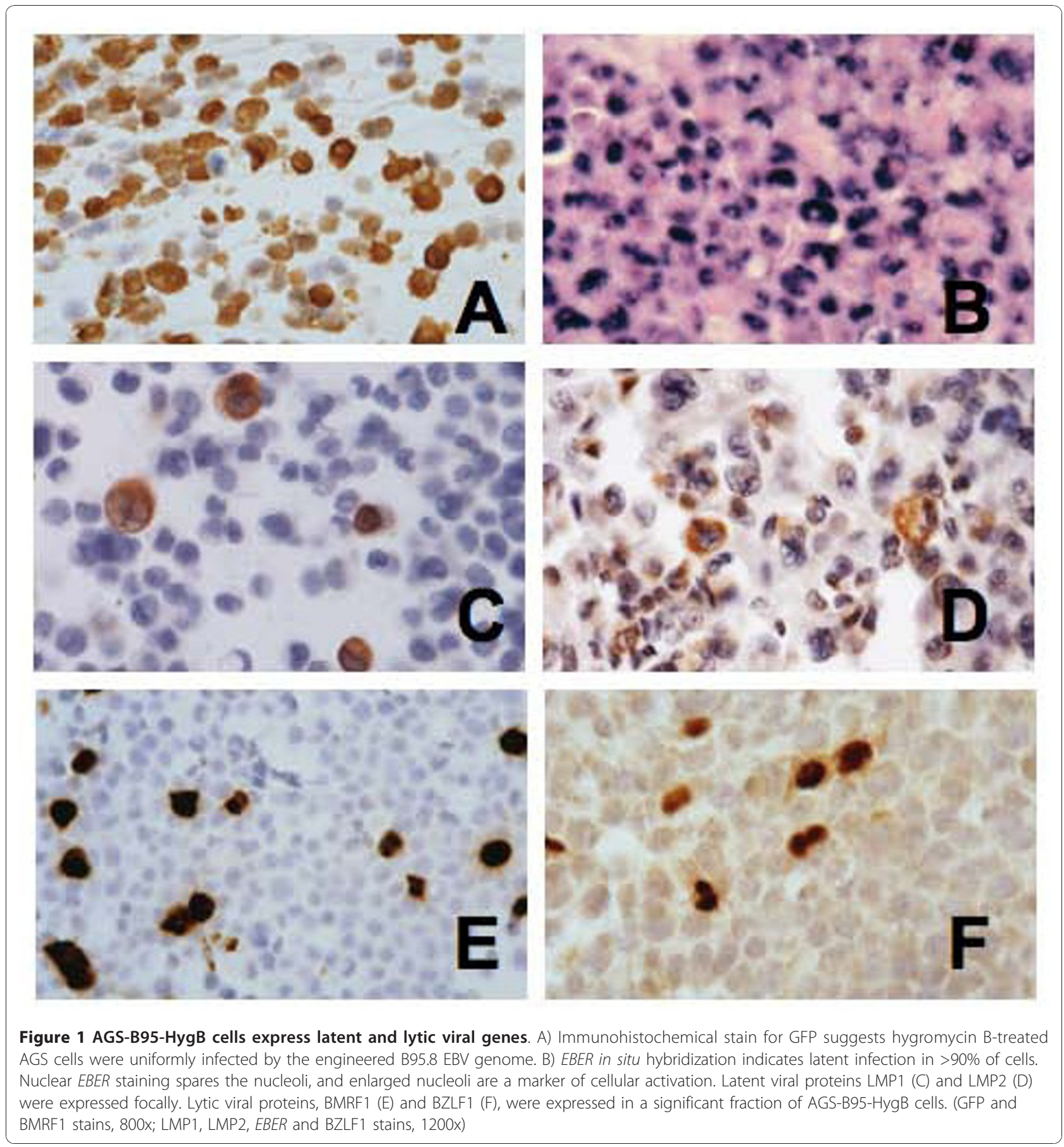

cells was found for $16 / 26$ genes (Table 2). The genes most strongly affected were IGFBP3 that was upregulated by 42 -fold, and COX2, BMP4, and ICAM1 that were downregulated by $35-, 32-$, and 22 -fold, respectively. The remaining ten microarray-based alterations were not confirmed by rtPCR, suggesting that EBVrelated dysregulation of these factors was lower than two-fold. In one instance, there was a major discrepancy: Expression levels of $B C L 2 L 1$ by microarray analysis showed a two-fold decrease in infected cells while rtPCR repeatedly showed a five-fold increase in BCL2L1 mRNA levels in infected cells. Less dramatic discrepancies were found when an additional 12 genes were analyzed by rtPCR, with significant $(>2$-fold) changes found in the expression of 5/12 genes for which no alteration was observed on the microarray (Table 2).

When rtPCR was used to evaluate expression of each of 5 selected genes (HLTF, BATF, ID4, TFF1, and NU) 


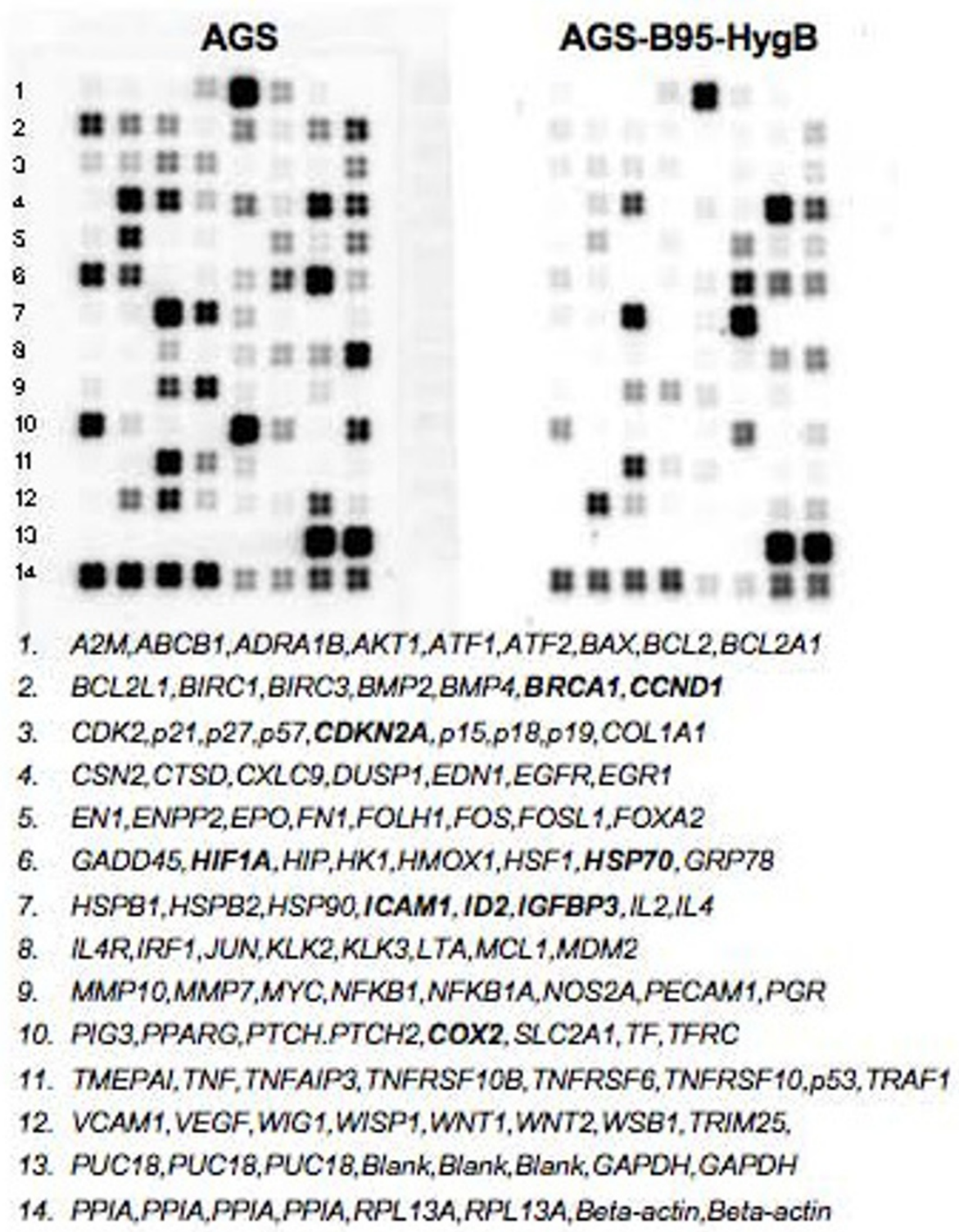

Figure 2 Gene expression patterns are altered by EBV infection of AGS cells. Biotin-labeled CDNA probes arrayed in quadruplicate on a nylon membrane hybridize to RNA isolated from AGS and AGS-B95-HygB cells. Chemiluminescent signals indicate dysregulation of selected genes among the 96 on the array as compared with control genes in the last two rows.

that were not on the microarray, all except for $H L T F$ was downregulated by more than five-fold in the EBVpositive AGS cells (Table 2). BATF and TFF1 were most significantly affected (38-fold and 21-fold decrease, respectively).

Demethylation Alters Cellular Gene Expression in AGS and AGS-B95-HygB cells

If gene promoter methylation contributed to EBVrelated alterations in gene expression, then demethylation could reverse the effect and perhaps even restore baseline gene expression. To explore this possibility, AGS and AGS-B95-HygB cells were cultured in the presence or absence of $5 \mathrm{aza}$. On the fourth day, RNA was isolated from treated and untreated cells, and rtPCR was performed to measure mRNA levels.

Figure 3 displays the effect of EBV infection on levels of 11 selected genes that encode proteins having a wide range of functions including cell cycle regulation and proliferation (CDKN2A/p16, CCND1, IGFBP3, HSP70, ID2, ID4), DNA repair (BRCA1, TFF1), cell adhesion (ICAM1), immune response (COX2), and angiogenesis 
Table 2 Genes Dysregulated in EBV-positive AGS Cells

\begin{tabular}{|c|c|c|}
\hline Gene Name & $\begin{array}{c}\text { Gene } \\
\text { Symbol }\end{array}$ & $\begin{array}{c}\text { Fold } \\
\text { Change* }\end{array}$ \\
\hline \multicolumn{3}{|c|}{ Downregulated Genes } \\
\hline $\begin{array}{l}\text { basic leucine-zipper transcription factor, } \\
\text { ATF-like }\end{array}$ & BATF & -38 \\
\hline cyclooxygenase-2 & $\operatorname{cox} 2$ & -35 \\
\hline bone morphogenic protein- 4 & BMP4 & -32 \\
\hline intercellular adhesion molecule-1 & ICAMI & -22 \\
\hline trefoil factor-1 & TFF1 & -21 \\
\hline inhibitor of DNA binding-2 & ID2 & -14 \\
\hline heat shock protein-70 & HSP70 & -10 \\
\hline cyclin-dependent kinase-2 & CDK2 & -9 \\
\hline cyclin-D1 & CCND1 & -9 \\
\hline hypoxia inducible factor-1A & HIFIA & -9 \\
\hline breast cancer-1 & $B R C A 1$ & -7 \\
\hline nucleostemin & NU & -7 \\
\hline cyclin-dependent kinase inhibitor-2A & CDKN2A/p16 & -6 \\
\hline inhibitor of DNA binding-4 & ID4 & -6 \\
\hline engrailed-1 & EN1 & -5 \\
\hline $\begin{array}{l}\text { ATP-binding cassette, sub-family B, } \\
\text { member } 1\end{array}$ & $A B C B 1$ & -3 \\
\hline MDM2 p53 binding protein & MDM2 & -3 \\
\hline \multicolumn{3}{|c|}{ Upregulated Genes } \\
\hline insulin-like growth factor binding protein-3 & IGFBP3 & +40 \\
\hline $\begin{array}{l}\text { tumor necrosis factor receptor-associated } \\
\text { factor-1 }\end{array}$ & TRAF1 & +20 \\
\hline $\begin{array}{l}\text { transmembrane prostate androgen-induced } \\
\text { protein }\end{array}$ & TMEPAI & +10 \\
\hline $\begin{array}{l}\text { tumor necrosis factor, superfamily } \\
\text { member-10 }\end{array}$ & TNFSF10 & +8 \\
\hline B cell lymphoma-2-like-1 & $B C L 2 L 1$ & +7 \\
\hline baculoviral IAP repeat containing-3 & $B I R C 3$ & +5 \\
\hline hexokinase-1 & $H K 1$ & +5 \\
\hline FOS-like antigen-1 & FOSL1 & +3 \\
\hline
\end{tabular}

*Listed are genes dysregulated by $>2$-fold using rtPCR

(HIF1A) [21,23,27,29-37]. Treatment with 5aza had varying effects depending on the gene and infection status. Five of the 11 genes (ID2, IGFBP3, CDKN2A, ID4, and $C C N D 1)$ responded to 5aza treatment with higher mRNA levels, consistent with promoter methylation in the parental AGS cells. In contrast, decreased expression of 4 factors (BRCA1, HIF1A, ICAM1, and COX2) was observed in response to 5 aza treatment, possibly because transcriptional repressors of these genes were demethylated. For the remaining factors (HSP70 and TFF1), 5aza had no significant effect in AGS cells, suggesting that these genes are not regulated by methylation in the absence of EBV.

In AGS-B95-HygB cells, reduced mRNA levels were observed for 10 genes upon EBV infection, but treatment with $5 \mathrm{aza}$ was not sufficient to fully restore expression of any of the genes except for ID2 and CCND1 where complete reversal of the downregulation was seen (Figure 3). For the remaining 8 genes there was partial restoration of expression upon demethylation.

IGFBP3 upregulation in uninfected cells treated with 5 aza suggests that an inhibitor of IGFBP3 is normally methylated in AGS cells, and that 5aza demethylates the inhibitor to induce IGFBP3. EBV infection also strongly induces $I G F B P 3$, but subsequent 5 aza treatment does not further induce gene expression rather it partly reverses the effect of EBV on IGFBP3 induction. Overall, these results suggest that methylation is a mechanism by which EBV influences cellular gene expression, and that demethylation can partially or completely restore baseline expression levels.

\section{Bisulfite DNA Sequencing Reveals EBV-specific Methylation}

Comparisons of methylation patterns were made between 5aza treated and untreated AGS and AGS-B95HygB cells to explore whether EBV-specific methylation was a plausible cause for dysregulation of five selected genes and to show how patterns of methylation were affected by $5 \mathrm{aza}$. The targeted promoter region for each gene contains multiple $\mathrm{CpG}$ dinucleotides: The CDKN2A region has 34 sites, ID4 has 53 sites, COX2 has 25 sites, ICAM1 has 35 sites, and TFF1 has 14 CpG sites.

Bisulfite sequencing showed CDKN2A ( $p 16$ ) was methylated at 30/34 CpG sites (88\%) in both AGS and AGS-B95-HygB cells. After 5aza treatment, only 22-31\% of sites remained methylated in AGS cells, whereas $70 \%$ of sites remained methylated in AGS-B95-HygB cells (Figure 4A) in concert with restored p16 expression from 24-fold to 6-fold below baseline (Figure 3). The findings imply a dramatic effect of EBV infection on p16 levels, and a more dramatic 5aza-related increase of p16 in infected cells compared to uninfected ones. The dramatic change in expression despite a minimal change in promoter methylation (88 to $70 \%$ ) after 5aza treatment of infected cells suggests the likelihood of mechanisms other than promoter demethylation.

EBV infection did not increase methylation of ID4 since its promoter was already largely methylated before infection occurred. Bisulfite sequence analysis of ID4 showed $96-100 \%$ methylation in both AGS and AGSB95-HygB cell lines (Figure 4B). Upon treatment with 5aza, methylation of $92-96 \%$ of CpG sites was seen in both infected and uninfected cells, and this seemingly small change in methylation status was accompanied by induction of ID4 mRNA. It is feasible that there is a non-methylation mechanism of ID4 regulation by EBV.

Interestingly, bisulfite sequencing analysis of $\mathrm{COX} 2$ showed that individual gene promoters were either completely unmethylated or else largely methylated in AGS 


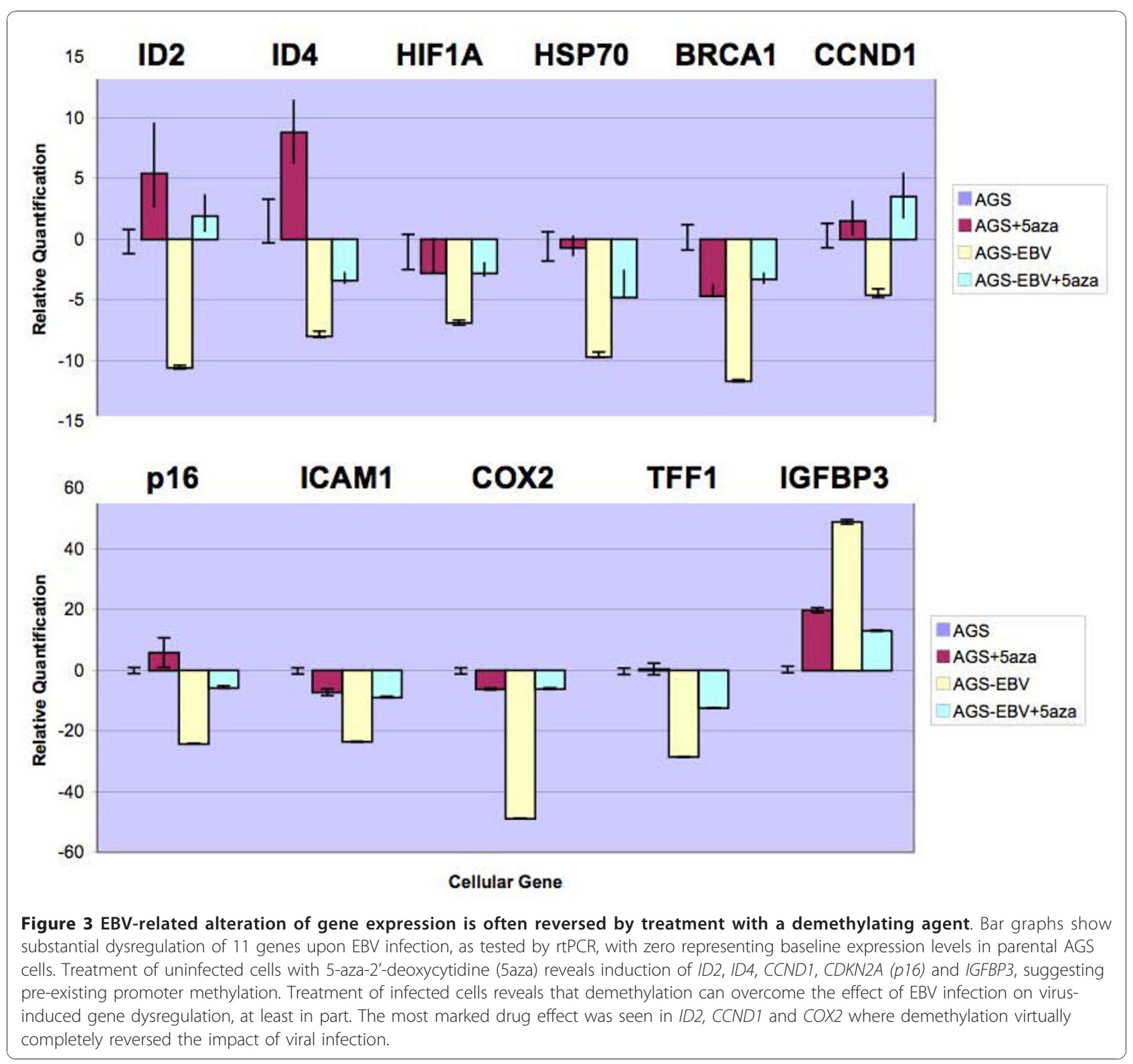

and in infected AGS cells, with somewhat different CpG hypermethylation patterns in infected compared to uninfected clones (Figure 4C) accompanied by a marked loss of COX2 expression (Figure 3). In the presence of 5 aza, there was dramatic demethylation of the COX2 promoter in AGS cells with only 0 to $6 \%$ methylation. In contrast, the COX2 promoter was either completely methylated or only half methylated in various clones of AGS-B95-HygB cells treated with 5aza, suggesting hemimethylation of alleles in a given cell or else cell-to-cell heterogeneity with respect to COX2 methylation patterns. On average, COX2 mRNA levels were similar in infected versus uninfected cells after treatment with 5aza. (Figure 3). Further work is needed to determine, in any given cell, how methylation status relates to COX2 levels and viral status (e.g. latent or lytic infection). In any case, EBV substantially influences COX2 expression and also impacts 5aza effects on its promoter.

ICAM1 had distinct methylation patterns in infected versus uninfected AGS cells, suggesting that EBV influences expression of this gene via promoter methylation (Figure 4D). Upon EBV infection, methylation of CpG sites increased slightly from 89 to $94 \%$, particularly at sites \#33 and 34, and this subtle change was associated with a pronounced decrease in ICAM1 expression. Treatment of both cell lines with 5aza yielded demethylation of $6-20 \%$ of the CpG sites to achieve similar 


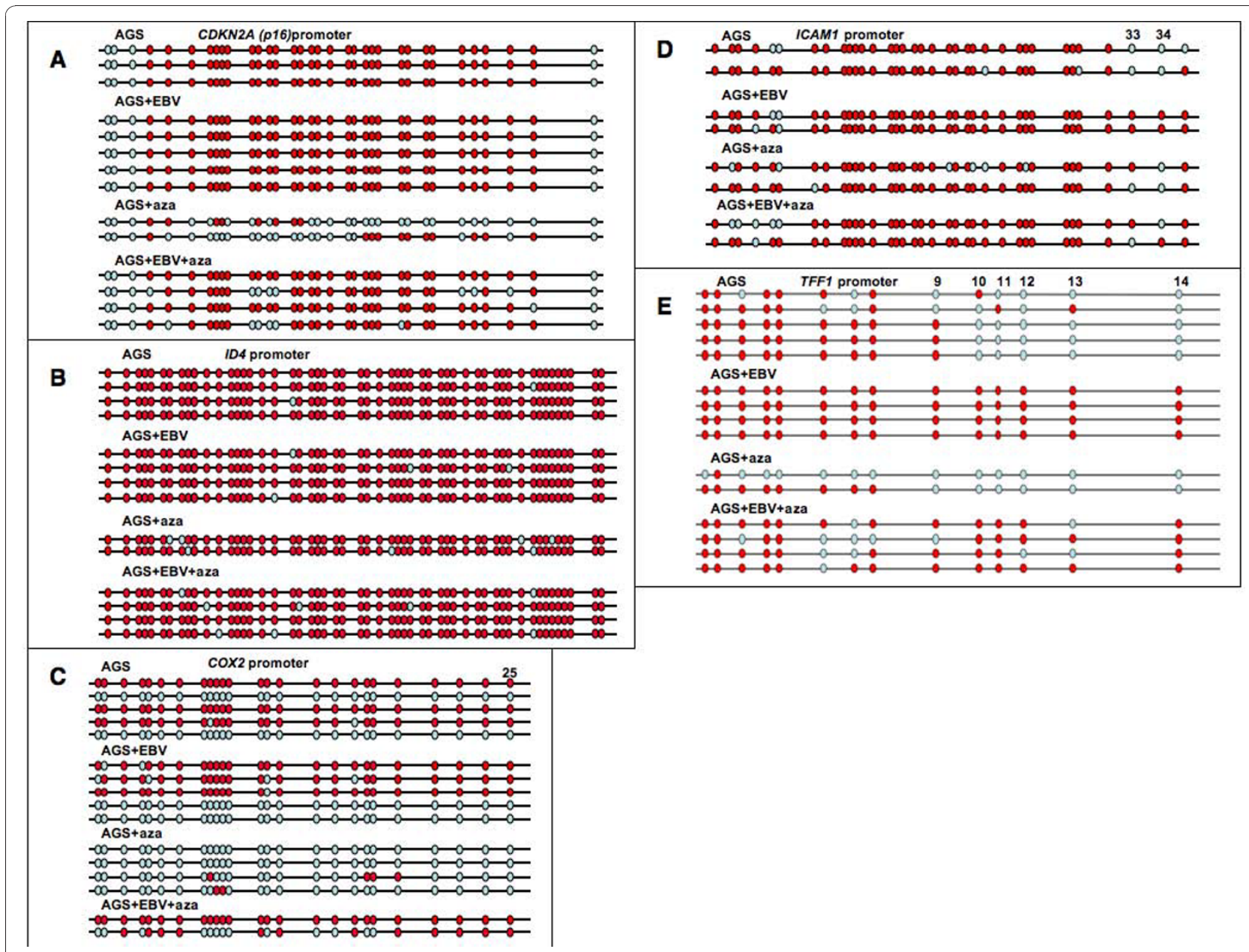

Figure 4 Promoter methylation is a plausible mechanism of EBV-mediated dysregulation of multiple genes. Bisulfite sequencing reveals methylation patterns of five genes: A) CDKN2A (p16), B) ID4, C) COX2, D) ICAMI, and E) TFF1. Methylation patterns are shown for several clones of each gene with or without EBV infection, and with or without 5-aza-2'-deoxycytidine (aza) treatment. In each clone, methylated sites are dark red ovals whereas unmethylated sites are light blue ovals.

mRNA levels, which in the infected AGS cells represented a restoration of levels from 24-fold to 9-fold below baseline.

The most dramatic viral-driven changes in promoter methylation were seen in the TFF1 gene. The TFF1 promoter was $50-64 \%$ methylated in AGS cells but 100\% methylated in the infected counterpart. In particular, CpG sites \#10-14 were methylated upon infection and tended to remain methylated even after attempting to demethylate them with 5aza (Figure 4E.) In EBV-positive AGS cells, 5aza demethylated $14-36 \%$ of sites and substantially induced TFF1 expression from 30 -fold to 12 fold below baseline, whereas in EBV-negative cells demethylation of $43-93 \%$ of sites had no effect on TFF1 expression. Overall, these findings provide evidence that EBV alters cellular gene expression by direct or indirect effects on promoter methylation, and demethylation can partially overcome viral effects on gene expression.
Protein-based analysis confirms virus-associated downregulation of COX2 in AGS cells but not in primary gastric adenocarcinoma tissues

COX2 was chosen for analysis at the protein level because of the translational potential for COX2 inhibitor therapy to overcome its effects. Lysates of EBV negative and EBV positive AGS cells were compared in western blot analysis. After normalization, COX2 expression in EBV-positive cells was 1.5 to 2.1 fold (average 1.9) lower than in EBV negative cells, confirming the RNA-based finding that $C O X 2$ levels are downregulated by EBV in this gastric epithelial cell line. In histologic sections of gastric adenocarcinoma, COX2 protein was localized to the cytoplasm and surface membrane of malignant cells, without significant staining of the nucleus. COX2 was also expressed in a fraction of tumor-infiltrating lymphoid cells. In EBER-negative cancers ( $\mathrm{n}=9)$, malignant cells had a mean proportion score of 3.3 and intensity 
score of 1.8, while EBV-positive cancers had a mean proportion score of 3.5 and intensity of 2.4. Total scores were not significantly different in relation to EBV status $(\mathrm{p}=0.07)$. Likewise, immunohistochemistry of AGS cells did not exhibit a visible difference in COX2 expression in relation to EBV status (Figure 5), suggesting that immunohistochemistry is less sensitive to changes in protein level than is western blot.

\section{Discussion}

Our research suggests that DNA methylation is a mechanism by which EBV alters cellular gene expression, and that virus-related methylation can be reversed, at least in part, by a demethylating agent. Since gross chromosomal abnormalities and microsatellite instability are less frequently detected in EBV-associated gastric cancer compared to EBV negative cancer, it is feasible that DNA hypermethylation is a primary driver of virusrelated oncogenesis that can be capitalized upon in designing therapeutic interventions [19,21].

It is difficult to analyze the natural effect of EBV infection on gastric cells because laboratory models only partially reflect the effects of EBV infection occurring in vivo. For example, LMP1 expression is unusual in naturally infected tumors whereas LMP1 was expressed in $10 \%$ of our infected AGS cells [2,63-71]. Low level lytic replication is sometimes reported in naturally infected gastric cancers while it is regularly reported in infected gastric cancer cell lines including our AGS-B95-HygB line $[2,65-69,72]$. Other limitations of this study are that only one gastric cell line was examined and the demethylating agent was applied for only three days. Nevertheless, our pilot work showing effects of EBV infection on cellular gene expression and promoter methylation in AGS cells encourages further investigation of the prospect of using demethylating agents to overcome virus-associated effects in vivo.

The observed viral replication in infected AGS cells might be aided by EBV-mediated downregulation of CCND1 and ID2 to achieve S-phase-like cellular conditions that are favorable for viral replication [73]. One of the EBV lytic proteins, $B M R F 1$, was previously shown to upregulate gastrin [74], and high levels of gastrin are implicated in gastric tumor development [75]. Lytic

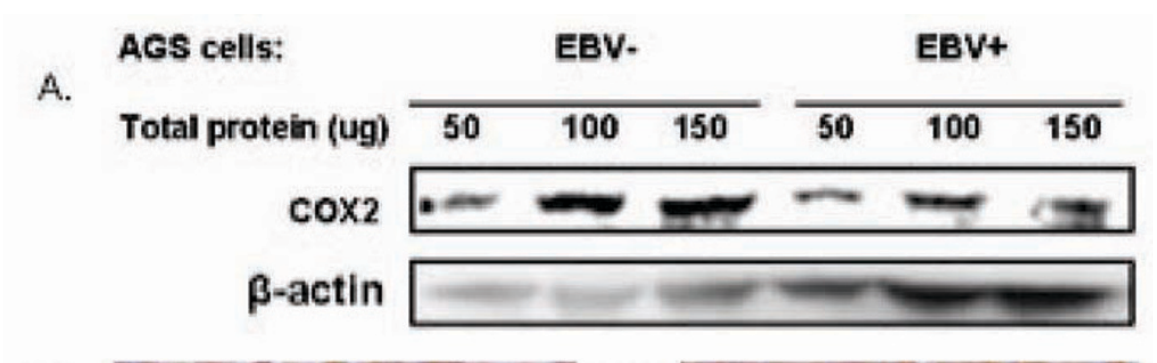

B.

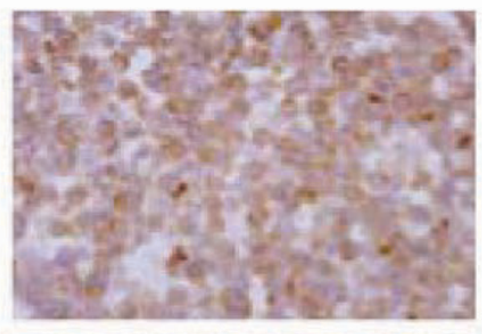

D.

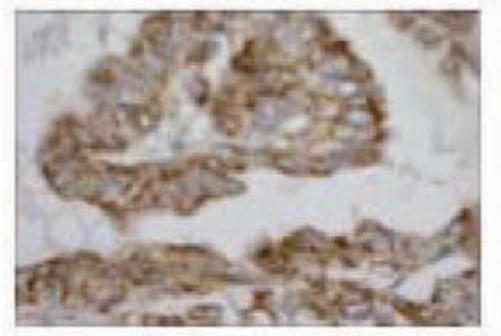

C.

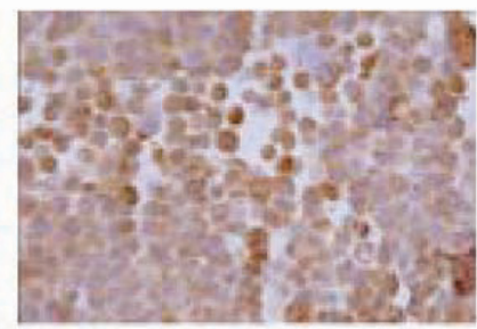

E.

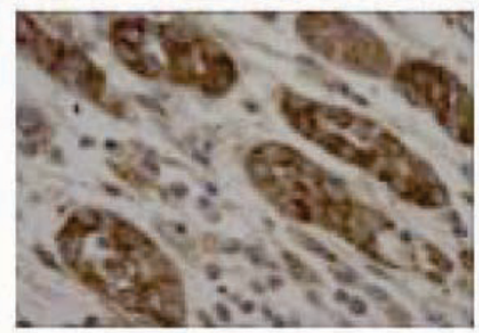

Figure 5 Western blot but not immunohistochemistry reveals downregulation of COX2 expression in association with EBV infection. Monclonal antibody was used to semiquantitatively measure COX2 protein. A. Western blot of AGS cell lysates (loaded onto the gel at 50, 100, or 150 ug per lane) showed that EBV positive AGS cells had lower expression of COX2 than did EBV negative cells. However, COX2 immunohistochemistry revealed no discernible difference between EBV negative (B) and EBV positive (C) AGS cell lines. Likewise, COX2 immunohistochemistry of primary gastric adenocarcinoma tissue revealed no visible difference in COX2 expression between EBV negative cancer (D) versus EBV positive cancer (E). 
infection is reportedly induced by $5 \mathrm{aza}$ [45], suggesting possible pathways of 5 aza effect beyond demethylating promoters. Khan et al showed TFF1 expression is directly induced by gastrin [76], so 5aza-mediated reversal of TFF1 loss might be explained in part by indirect effects on viral replication and gastrin induction in addition to the observed demethylation of the TFF1 promoter. TFF1, which encodes trefoil factor 1, is suggested to be a tumor suppressor gene that is lost or methylated in many gastric cancers [77]. Interestingly, prior studies suggest that EBV-related hypermethylation is stimulated by pre-existing promoter methylation $[19,21,29]$, and our data on TFF1 as well as ICAM1 promoters would support this characteristic.

Prior studies showed loss of ID4 expression in about $30 \%$ of gastric cancer as well as a means to upregulate ID4 using 5aza in gastric cell lines [32]. Our work shed light on the impact of EBV infection by demonstrating strong downregulation of ID2 and ID4 upon infection. ID2 and ID4 are members of a family of "inhibitor of differentiation" transcriptional regulators. In breast cancer, methylation-related silencing of ID4 is a poor prognostic indicator, and demethylation is proposed as a means of overcoming ID4 repression [78]. In our own demethylation studies, we showed that ID2 and ID4 silencing could be reversed by 5 aza in AGS cells.

COX2 encodes an enzyme critical for prostaglandin production that mediates inflammation in the gastrointestinal tract. COX2 may contribute to carcinogenesis by promoting apoptosis resistance, angiogenesis, invasiveness, and by affecting host immunity [79-88]. COX2 gene silencing by hypermethylation in gastric carcinoma cells was previously reported $[18,89,90]$. Our data show that EBV infection causes a 50-fold decrease in COX2 mRNA levels in infected compared to uninfected AGS cells. At the protein level, western blot confirmed downregulation of COX2 in EBV-infected AGS cells although the magnitude of change was less dramatic at about two-fold. Nearly complete restoration of baseline mRNA expression upon demethylation suggests a potential pharmacologic means of reversing the viral effect. The clinical implications of such a finding are intriguing given the reported beneficial effects of COX2 inhibition on incidence, recurrence and outcome of gastrointestinal malignancy $[88,91]$. Follow-up studies are warranted to explore if COX2 testing of gastric cancer tissue identifies patients most likely to benefit from COX2 inhibition. RNA-based assays may be more informative than immunohistochemistry given our evidence that immunostains were uniquely incapable of quantifying changes in COX2 levels in response to EBV infection of AGS cells. Another group found that COX2 immunostain results were prognostic even though they were not
EBV-associated in a series of patients treated for gastric cancer [92].

Heritable polymorphisms in COX2 and in IGFBP3 have been reported to affect the risk of developing gastric cancer $[91,93,94]$. IGFBP3 is thought to reduce gastric cancer metastasis by sequestering IGFs to prevent them from triggering receptor tyrosine kinases [95]. Methylation of the IGFBP3 promoter is found in $67 \%$ of gastric cancers, and its silencing is predicted to increase tumor aggressiveness [96]. Our data on upregulation of IGFBP3 in response to 5 aza treatment confirms a previous study done on uninfected AGS cells [43]. Interestingly, Lee et al reported that high IGFBP3 expression is a positive predictive marker for response to the antineoplastic drugs paclitaxel and etoposide, suggesting that EBV-infected cancers overexpressing IGFBP3 might be particularly susceptible to these chemotherapeutic agents [97]. If confirmed, these insights could impact tumor classification schemes and assist in managing patients with gastric cancer.

\section{Conclusions}

EBV infection had a profound effect on expression of $I G F B P 3$. Unlike IGFBP3 transcripts which were upregulated, most of the tested gene were downregulated by EBV infection. Methylation may be a common mechanism for diverse effects of viral infection. To the extent that viral infection is associated with methylation in vivo, demethylating agents could provide a unified therapeutic approach to overcoming viral effects.

Demethylating agents are already used clinically for managing certain neoplasms [98], and their efficacy in EBV-related gastric cancer should be considered. Our pilot data shows frequent and substantial restoration of multiple transcripts in 5aza-treated, infected cells. Pilot sequencing data identify selective effects of virus infection and 5aza treatment on promoter methylation, providing an impetus for further work to characterize viral-mediated effects and to understand how treatments might be devised to overcome viral effects in tumor cells.

\section{Acknowledgements}

The authors thank Hongxin Fan, MD for developing the BamH1W EBV viral load assay, and Dr. Henri J. Delecluse for providing the recombinant EBV strain. This study was sponsored by grants from the National Cancer Institute (R01CA058853 and T32-ES07017) and by the University of North Carolina Department of Pathology and Laboratory Medicine. We are also grateful for support from the University Cancer Research Fund of the Lineberger Comprehensive Cancer Center, the NC Translational and Clinical Sciences Institute, and the Translational Pathology Laboratory, Genomics and Bioinformatics Core Facility, Nucleic Acids Core Facility, Genome Analysis Facility, and the GI SPORE group (P50 CA106991) of the University of North Carolina at Chapel Hill. 


\section{Author details}

'Departments of Dermatology \& Radiation Oncology, University of Rochester Medical Center, Rochester, NY 14642-8704, USA. ${ }^{2}$ Department of Lymphoma and Myeloma, MD Anderson Cancer Center, Houston, TX 77054, USA. ${ }^{3}$ Departments of Oncology and Medicine, McArdle Laboratory, University of Wisconsin School of Medicine and Public Health, Madison, WI 53706, USA. ${ }^{4}$ Department of Pathology and Laboratory Medicine and the Lineberger Comprehensive Cancer Center, University of North Carolina, Chapel Hill, NC 27599-7525, USA.

\section{Authors' contributions}

All authors read and approved the final manuscript. JLR designed experiments, contributed and analyzed data, and drafted the manuscript. RJJ prepared cell lines and revised the manuscript. SCK conceived the idea, provided access to cell lines, and revised the manuscript. AGR designed methylation assays and revised the manuscript. WT validated and applied histochemical stains, and revised the manuscript. ERWK validated and applied COX2 immunostains, and revised the manuscript. WBC participated in study design and revised the manuscript. MLG designed experiments, supervised benchwork, interpreted data, and revised the manuscript.

\section{Competing interests}

MLG serves on advisory board of Generation Health, and is a consultant for McKesson, Abbott Laboratories, Roche Molecular Diagnostics, and Scientia Advisors,

Received: 24 August 2010 Accepted: 31 December 2010 Published: 31 December 2010

\section{References}

1. Correa P, Piazuelo MB, Camargo MC: The future of gastric cancer prevention. Gastric Cancer 2004, 7:9-16.

2. Gulley ML, Pulitzer DR, Eagan PA, Schneider BG: Epstein-Barr virus infection is an early event in gastric carcinogenesis and is independent of bcl-2 expression and p53 accumulation. Hum Pathol 1996, 27:20-27.

3. Murphy G, Pfeiffer R, Camargo MC, Rabkin CS: Meta-analysis shows that prevalence of Epstein-Barr virus-positive gastric cancer differs based on sex and anatomic location. Gastroenterology 2009, 137:824-833.

4. Lee JH, Kim SH, Han SH, An JS, Lee ES, Kim YS: Clinicopathological and molecular characteristics of Epstein-Barr virus-associated gastric carcinoma: a meta-analysis. J Gastroenterol Hepatol 2009, 24:354-365.

5. Cho HJ, Kim JY, Yoo J, Lee SS: Gastric carcinoma with lymphoid stroma: incidence of EBV and Helicobacter pylori infection. App/ Immunohistochem Mol Morphol 2003, 11:149-152

6. Fukayama M, Chong JM, Uozaki H: Pathology and molecular pathology of Epstein-Barr virus-associated gastric carcinoma. Curr Top Microbiol Immunol 2001, 258:91-102.

7. Nakamura S, Ueki T, Yao T, Ueyama T, Tsuneyoshi M: Epstein-Barr virus in gastric carcinoma with lymphoid stroma. Special reference to its detection by the polymerase chain reaction and in situ hybridization in 99 tumors, including a morphologic analysis. Cancer 1994, 73:2239-2249.

8. van Beek J, zur Hausen A, Klein Kranenbarg E, van de Velde CJ, Middeldorp JM, van den Brule AJ, Meijer CJ, Bloemena E: EBV-positive gastric adenocarcinomas: a distinct clinicopathologic entity with a low frequency of lymph node involvement. J Clin Oncol 2004, 22:664-670.

9. Zazula M, Ferreira AM, Czopek JP, Kolodziejczyk P, Sinczak-Kuta A, Klimkowska A, Wojcik P, Okon K, Bialas M, Kulig J, Stachura J: CDH1 gene promoter hypermethylation in gastric cancer: relationship to Goseki grading, microsatellite instability status, and EBV invasion. Diagn Mol Pathol 2006, 15:24-29.

10. Vauhkonen $\mathrm{M}$, Vauhkonen $\mathrm{H}$, Sipponen P: Pathology and molecular biology of gastric cancer. Best Pract Res Clin Gastroenterol 2006, 20:651-674

11. Chang MS, Uozaki H, Chong JM, Ushiku T, Sakuma K, Ishikawa S, Hino R, Barua RR, Iwasaki Y, Arai K, Fujii H, Nagai H, Fukayama M: CpG island methylation status in gastric carcinoma with and without infection of Epstein-Barr virus. Clin Cancer Res 2006, 12:2995-3002.

12. Sudo M, Chong JM, Sakuma K, Ushiku T, Uozaki H, Nagai H, Funata N, Matsumoto Y, Fukayama M: Promoter hypermethylation of E-cadherin and its abnormal expression in Epstein-Barr virus-associated gastric carcinoma. Int J Cancer 2004, 109:194-199.
13. Lee HS, Chang MS, Yang HK, Lee BL, Kim WH: Epstein-barr virus-positive gastric carcinoma has a distinct protein expression profile in comparison with epstein-barr virus-negative carcinoma. Clin Cancer Res 2004, 10:1698-1705.

14. Schneider BG, Gulley ML, Eagan P, Bravo JC, Mera R, Geradts J: Loss of p16/ CDKN2A tumor suppressor protein in gastric adenocarcinoma is associated with Epstein-Barr virus and anatomic location in the body of the stomach. Hum Pathol 2000, 31:45-50.

15. Vo QN, Geradts J, Gulley ML, Boudreau DA, Bravo JC, Schneider BG: Epstein-Barr virus in gastric adenocarcinomas: association with ethnicity and CDKN2A promoter methylation. J Clin Pathol 2002, 55:669-675.

16. Carneiro F, Oliveira C, Leite M, Seruca R: Molecular targets and biological modifiers in gastric cancer. Semin Diagn Pathol 2008, 25:274-287.

17. Ushiku T, Chong JM, Uozaki H, Hino R, Chang MS, Sudo M, Rani BR, Sakuma K, Nagai H, Fukayama M: p73 gene promoter methylation in Epstein-Barr virus-associated gastric carcinoma. Int J Cancer 2007, 120:60-66

18. Ferrasi AC, Pinheiro NA, Rabenhorst $\mathrm{SH}$, Caballero OL, Rodrigues MA, de Carvalho F, Leite CV, Ferreira MV, Barros MA, Pardini Ml: Helicobacter pylori and EBV in gastric carcinomas: methylation status and microsatellite instability. World J Gastroenterol 2010, 16:312-319.

19. Kang GH, Lee S, Kim WH, Lee HW, Kim JC, Rhyu MG, Ro JY: Epstein-barr virus-positive gastric carcinoma demonstrates frequent aberrant methylation of multiple genes and constitutes $\mathrm{CpG}$ island methylator phenotype-positive gastric carcinoma. Am J Pathol 2002, 160:787-794.

20. Ksiaa F, Ziadi S, Amara K, Korbi S, Trimeche M: Biological significance of promoter hypermethylation of tumor-related genes in patients with gastric carcinoma. Clin Chim Acta 2009, 404:128-133.

21. Chong JM, Sakuma K, Sudo M, Ushiku T, Uozaki H, Shibahara J, Nagai H, Funata N, Taniguchi H, Aburatani H, Fukayama M: Global and non-random CpG-island methylation in gastric carcinoma associated with EpsteinBarr virus. Cancer Sci 2003, 94:76-80.

22. Kang GH, Lee S, Cho NY, Gandamihardja T, Long TI, Weisenberger DJ, Campan M, Laird PW: DNA methylation profiles of gastric carcinoma characterized by quantitative DNA methylation analysis. Lab Invest 2008 , 88:161-170.

23. Niller $H H$, Wolf $H$, Minarovits J: Epigenetic dysregulation of the host cell genome in Epstein-Barr virus-associated neoplasia. Semin Cancer Biol 2009, 19:158-164.

24. Kusano M, Toyota M, Suzuki H, Akino K, Aoki F, Fujita M, Hosokawa M, Shinomura Y, Imai K, Tokino T: Genetic, epigenetic, and clinicopathologic features of gastric carcinomas with the $\mathrm{CpG}$ island methylator phenotype and an association with Epstein-Barr virus. Cancer 2006, 106:1467-1479.

25. Fukayama M: Epstein-Barr virus and gastric carcinoma. Pathol Int 2010, 60:337-350.

26. Park SY, Kook MC, Kim YW, Cho NY, Kim TY, Kang GH: Mixed-type gastric cancer and its association with high-frequency CpG island hypermethylation. Virchows Arch 2010, 456:625-633.

27. Etoh T, Kanai Y, Ushijima S, Nakagawa T, Nakanishi Y, Sasako M, Kitano S, Hirohashi S: Increased DNA methyltransferase 1 (DNMT1) protein expression correlates significantly with poorer tumor differentiation and frequent DNA hypermethylation of multiple $\mathrm{CpG}$ islands in gastric cancers. Am J Pathol 2004, 164:689-699.

28. Hino R, Uozaki H, Murakami N, Ushiku T, Shinozaki A, Ishikawa S, Morikawa T, Nakaya T, Sakatani T, Takada K, Fukayama M: Activation of DNA methyltransferase 1 by EBV latent membrane protein $2 \mathrm{~A}$ leads to promoter hypermethylation of PTEN gene in gastric carcinoma. Cancer Res 2009, 69:2766-2774.

29. Sakakura C, Hagiwara A, Nakanishi M, Shimomura K, Takagi T, Yasuoka R, Fujita Y, Abe T, Ichikawa Y, Takahashi S, Ishikawa T, Nishizuka I, Morita T, Shimada H, Okazaki Y, Hayashizaki Y, Yamagishi H: Differential gene expression profiles of gastric cancer cells established from primary tumour and malignant ascites. Br J Cancer 2002, 87:1153-1161.

30. Tsai CL, Li HP, Lu YJ, Hsueh C, Liang Y, Chen CL, Tsao SW, Tse KP, Yu JS, Chang YS: Activation of DNA methyltransferase 1 by EBV LMP1 Involves c-Jun NH(2)-terminal kinase signaling. Cancer Res 2006, 66:11668-11676.

31. Tsai CN, Tsai CL, Tse KP, Chang HY, Chang YS: The Epstein-Barr virus oncogene product, latent membrane protein 1 , induces the downregulation of E-cadherin gene expression via activation of DNA methyltransferases. Proc Natl Acad Sci USA 2002, 99:10084-10089. 
32. Chan AS, Tsui WY, Chen X, Chu KM, Chan TL, Li R, So S, Yuen ST, Leung SY: Downregulation of ID4 by promoter hypermethylation in gastric adenocarcinoma. Oncogene 2003, 22:6946-6953.

33. Li H, Minarovits J: Host cell-dependent expression of latent Epstein-Barr virus genomes: regulation by DNA methylation. Adv Cancer Res 2003, 89:133-156.

34. Dickerson SJ, Xing Y, Robinson AR, Seaman WT, Gruffat H, Kenney SC: Methylation-dependent binding of the epstein-barr virus BZLF1 protein to viral promoters. PLoS Pathog 2009, 5:e1000356.

35. Bhende PM, Seaman WT, Delecluse HJ, Kenney SC: The EBV lytic switch protein, Z, preferentially binds to and activates the methylated viral genome. Nat Genet 2004, 36:1099-1104.

36. Watanabe Y, Kim HS, Castoro RJ, Chung W, Estecio MR, Kondo K, Guo Y, Ahmed SS, Toyota M, Itoh F, Suk KT, Cho MY, Shen L, Jelinek J, Issa JP: Sensitive and specific detection of early gastric cancer with DNA methylation analysis of gastric washes. Gastroenterology 2009, 136:2149-2158.

37. van Beek J, zur Hausen A, Kranenbarg EK, Warring RJ, Bloemena E, Craanen ME, van de Velde CJ, Middeldorp JM, Meijer CJ, van den Brule AJ: A rapid and reliable enzyme immunoassay PCR-based screening method to identify EBV-carrying gastric carcinomas. Mod Pathol 2002, 15:870-877.

38. zur Hausen A, Brink AA, Craanen ME, Middeldorp JM, Meijer CJ, van den Brule AJ: Unique transcription pattern of Epstein-Barr virus (EBV) in EBVcarrying gastric adenocarcinomas: expression of the transforming BARF1 gene. Cancer Research 2000, 60:2745-2748.

39. Houali K, Wang X, Shimizu Y, Djennaoui D, Nicholls J, Fiorini S, Bouguermouh A, Ooka T: A new diagnostic marker for secreted EpsteinBarr virus encoded LMP1 and BARF1 oncoproteins in the serum and saliva of patients with nasopharyngeal carcinoma. Clin Cancer Res 2007, 13:4993-5000

40. Stevens SJ, Verkuijlen SA, Hariwiyanto B, Harijadi, Paramita DK, Fachiroh J, Adham M, Tan IB, Haryana SM, Middeldorp JM: Noninvasive diagnosis of nasopharyngeal carcinoma: nasopharyngeal brushings reveal high Epstein-Barr virus DNA load and carcinoma-specific viral BARF1 mRNA. Int J Cancer 2006, 119:608-614.

41. Suzuki $H$, Toyota $M$, Kondo $Y$, Shinomura $Y$ : Inflammation-related aberrant patterns of DNA methylation: detection and role in epigenetic deregulation of cancer cell transcriptome. Methods Mol Biol 2009, 512:55-69.

42. Toyota M, Suzuki H, Yamashita T, Hirata K, Imai K, Tokino T, Shinomura Y: Cancer epigenomics: implications of DNA methylation in personalized cancer therapy. Cancer Sci 2009, 100:787-791.

43. Yamashita S, Tsujino Y, Moriguchi K, Tatematsu M, Ushijima T: Chemical genomic screening for methylation-silenced genes in gastric cancer cell lines using 5-aza-2'-deoxycytidine treatment and oligonucleotide microarray. Cancer Sci 2006, 97:64-71.

44. Mikata R, Yokosuka O, Fukai K, Imazeki F, Arai M, Tada M, Kurihara T, Zhang K, Kanda T, Saisho H: Analysis of genes upregulated by the demethylating agent 5-aza-2'-deoxycytidine in gastric cancer cell lines. Int J Cancer 2006, 119:1616-1622.

45. Jung EJ, Lee YM, Lee BL, Chang MS, Kim WH: Lytic induction and apoptosis of Epstein-Barr virus-associated gastric cancer cell line with epigenetic modifiers and ganciclovir. Cancer Lett 2007, 247:77-83.

46. Mitsuno M, Kitajima Y, Ide T, Ohtaka K, Tanaka M, Satoh S, Miyazaki K: Aberrant methylation of p16 predicts candidates for 5 -fluorouracil-based adjuvant therapy in gastric cancer patients. J Gastroenterol 2007, 42:866-873.

47. Feng WH, Westphal E, Mauser A, Raab-Traub N, Gulley ML, Busson P, Kenney SC: Use of adenovirus vectors expressing Epstein-Barr virus (EBV) immediate-early protein BZLF1 or BRLF1 to treat EBV-positive tumors. J Virol 2002, 76:10951-10959.

48. Kassis J, Maeda A, Teramoto N, Takada K, Wu C, Klein G, Wells A: EBVexpressing AGS gastric carcinoma cell sublines present increased motility and invasiveness. Int J Cancer 2002, 99:644-651.

49. Kang GH, Lee S, Kim JS, Jung HY: Profile of aberrant CpG island methylation along the multistep pathway of gastric carcinogenesis. Lab Invest 2003, 83:635-641.

50. Varis A, Zaika A, Puolakkainen P, Nagy B, Madrigal I, Kokkola A, Vayrynen A, Karkkainen P, Moskaluk C, El-Rifai W, Knuutila S: Coamplified and overexpressed genes at ERBB2 locus in gastric cancer. Int I Cancer 2004, 109:548-553.
51. Hong GK, Delecluse HJ, Gruffat $H$, Morrison TE, Feng WH, Sergeant A, Kenney SC: The BRRF1 early gene of Epstein-Barr virus encodes a transcription factor that enhances induction of lytic infection by BRLF1. J Virol 2004, 78:4983-4992.

52. Ryan JL, Fan H, Glaser SL, Schichman SA, Raab-Traub N, Gulley ML: EpsteinBarr virus quantitation by real-time $P C R$ targeting multiple gene segments: a novel approach to screen for the virus in paraffinembedded tissue and plasma. J Mol Diagn 2004, 6:378-385.

53. Ling PD, Vilchez RA, Keitel WA, Poston DG, Peng RS, White ZS, Visnegarwala F, Lewis DE, Butel JS: Epstein-Barr virus DNA loads in adult human immunodeficiency virus type 1-infected patients receiving highly active antiretroviral therapy. Clin Infect Dis 2003, 37:1244-1249.

54. Hamai Y, Oue N, Mitani Y, Nakayama H, Ito R, Matsusaki K, Yoshida K, Toge T, Yasui W: DNA hypermethylation and histone hypoacetylation of the HLTF gene are associated with reduced expression in gastric carcinoma. Cancer Sci 2003, 94:692-698.

55. Katoh M: Trefoil factors and human gastric cancer. Int J Mol Med 2003, 12:3-9.

56. Leung WK, Yu J, Bai AH, Chan MW, Chan KK, To KF, Chan FK, Ng EK, Chung SC, Sung JJ: Inactivation of helicase-like transcription factor by promoter hypermethylation in human gastric cancer. Mol Carcinog 2003, 37:91-97.

57. Liu SJ, Cai ZW, Liu YJ, Dong MY, Sun LQ, HU GF, Wei YY, Lao WD: Role of nucleostemin in growth regulation of gastric cancer, liver cancer, and other malignancies. World J Gastroenterol 2004, 10:1246-1249.

58. Meyer NP, Johansen LM, Tae HJ, Budde PP, Williams KL, Taparowsky EJ: Genomic organization of human B-ATF, a target for regulation by EBV and HTLV-1. Mamm Genome 1998, 9:849-852.

59. Ren JL, Luo JY, Lu YP, Wang L, Shi HX: Relationship between trefoil factor 1 expression and gastric mucosa injuries and gastric cancer. World J Gastroenterol 2005, 11:2674-2677.

60. Rivenbark AG, Jones WD, Coleman WB: DNA methylation-dependent silencing of CST6 in human breast cancer cell lines. Lab Invest 2006, 86:1233-1242.

61. Rivenbark AG, Jones WD, Risher JD, Coleman WB: DNA methylationdependent epigenetic regulation of gene expression in MCF-7 breast cancer cells. Epigenetics 2006, 1:32-44.

62. Gardiner-Garden M, Frommer M: CpG islands in vertebrate genomes. J Mol Biol 1987, 196:261-282.

63. Akiba S, Koriyama C, Herrera-Goepfert R, Eizuru Y: Epstein-Barr virus associated gastric carcinoma: epidemiological and clinicopathological features. Cancer Sci 2008, 99:195-201.

64. Kida Y, Miyauchi K, Takano Y: Gastric adenocarcinoma with differentiation to sarcomatous components associated with monoclonal Epstein-Barr virus infection and LMP-1 expression. Virchows Arch A Pathol Anat Histopathol 1993, 423:383-387.

65. Feng WH, Kraus RJ, Dickerson SJ, Lim HJ, Jones RJ, Yu X, Mertz JE, Kenney SC: ZEB1 and c-Jun levels contribute to the establishment of highly lytic Epstein-Barr virus infection in gastric AGS cells. J Virol 2007, 81:10113-10122.

66. Huang J, Liao G, Chen H, Wu FY, Hutt-Fletcher L, Hayward GS, Hayward SD: Contribution of C/EBP proteins to Epstein-Barr virus lytic gene expression and replication in epithelial cells. J Virol 2006, 80:1098-1109.

67. Chen JN, Ding YG, Feng ZY, Li HG, He D, Du H, Wu B, Shao CK: Association of distinctive Epstein-Barr virus variants with gastric carcinoma in Guangzhou, southern China. J Med Virol 82:658-667.

68. Oh ST, Seo JS, Moon UY, Kang KH, Shin DJ, Yoon SK, Kim WH, Park JG, Lee SK: A naturally derived gastric cancer cell line shows latency I Epstein-Barr virus infection closely resembling EBV-associated gastric cancer. Virology 2004, 320:330-336.

69. zur Hausen A, Brink AA, Craanen ME, Middeldorp JM, Meijer CJ, van den Brule AJ: Unique transcription pattern of Epstein-Barr virus (EBV) in EBVcarrying gastric adenocarcinomas: expression of the transforming BARF1 gene. Cancer Res 2000, 60:2745-2748.

70. Sheu LF, Chen A, Wei YH, Ho KC, Cheng JY, Meng CL, Lee WH: Epstein-Barr virus LMP1 modulates the malignant potential of gastric carcinoma cells involving apoptosis. Am J Pathol 1998, 152:63-74.

71. Luo B, Wang Y, Wang XF, Gao Y, Huang BH, Zhao P: Correlation of Epstein-Barr virus and its encoded proteins with Helicobacter pylori and expression of c-met and c-myc in gastric carcinoma. World I Gastroenterol 2006, 12:1842-1848. 
72. Luo B, Wang Y, Wang XF, Liang H, Yan LP, Huang BH, Zhao P: Expression of Epstein-Barr virus genes in EBV-associated gastric carcinomas. World J Gastroenterol 2005, 11:629-633.

73. Tsurumi T, Fujita M, Kudoh A: Latent and lytic Epstein-Barr virus replication strategies. Rev Med Virol 2005, 15:3-15.

74. Holley-Guthrie EA, Seaman WT, Bhende P, Merchant JL, Kenney SC: The Epstein-Barr virus protein BMRF1 activates gastrin transcription. J Virol 2005, 79:745-755.

75. Burkitt MD, Varro A, Pritchard DM: Importance of gastrin in the pathogenesis and treatment of gastric tumors. World I Gastroenterol 2009, 15:1-16.

76. Khan ZE, Wang TC, Cui G, Chi AL, Dimaline R: Transcriptional regulation of the human trefoil factor, TFF1, by gastrin. Gastroenterology 2003, 125:510-521.

77. Carvalho R, Kayademir T, Soares P, Canedo P, Sousa S, Oliveira C, Leistenschneider P, Seruca R, Gott P, Blin N, Carneiro F, Machado JC: Loss of heterozygosity and promoter methylation, but not mutation, may underlie loss of TFF1 in gastric carcinoma. Lab Invest 2002, 82:1319-1326.

78. Noetzel E, Veeck J, Niederacher D, Galm O, Horn F, Hartmann A, Knuchel R, Dahl E: Promoter methylation-associated loss of ID4 expression is a marker of tumour recurrence in human breast cancer. BMC Cancer 2008 8:154.

79. Iglesias D, Nejda N, Azcoita MM, Schwartz S Jr, Gonzalez-Aguilera JJ, Fernandez-Peralta AM: Effect of COX2 $-765 \mathrm{G}>\mathrm{C}$ and c.3618A $>\mathrm{G}$ polymorphisms on the risk and survival of sporadic colorectal cancer. Cancer Causes Control 2009, 20:1421-1429.

80. Okano H, Shinohara H, Miyamoto A, Takaori K, Tanigawa N: Concomitant overexpression of cyclooxygenase-2 in HER-2-positive on Smad4reduced human gastric carcinomas is associated with a poor patient outcome. Clin Cancer Res 2004, 10:6938-6945.

81. Ono HA, Davydova JG, Adachi Y, Takayama K, Barker SD, Reynolds PN, Krasnykh VN, Kunisaki C, Shimada H, Curiel DT, Yamamoto M: Promotercontrolled infectivity-enhanced conditionally replicative adenoviral vectors for the treatment of gastric cancer. J Gastroenterol 2005, 40:31-42.

82. Fukuhara K, Osugi H, Takada N, Takemura M, Lee S, Morimura K, Taguchi S, Kaneko M, Tanaka Y, Fujiwara Y, Nishizawa S, Fukushima S, Kinoshita H: Effect of H. pylori on COX-2 expression in gastric remnant after distal gastrectomy. Hepatogastroenterology 2004, 51:1515-1518.

83. Chen $X L$, Su BS, Sun RQ, Zhang J, Wang YL: Relationship between expression and distribution of cyclooxygenase- 2 and bcl-2 in human gastric adenocarcinoma. World I Gastroenterol 2005, 11:1228-1231.

84. Koga T, Shibahara K, Kabashima A, Sumiyoshi Y, Kimura Y, Takahashi I, Kakeji Y, Maehara Y: Overexpression of cyclooxygenase-2 and tumor angiogenesis in human gastric cancer. Hepatogastroenterology 2004, 51:1626-1630.

85. Jang TJ: Expression of proteins related to prostaglandin E2 biosynthesis is increased in human gastric cancer and during gastric carcinogenesis. Virchows Arch 2004, 445:564-571.

86. Nardone G, Rocco A, Vaira D, Staibano S, Budillon A, Tatangelo F, Sciulli MG Perna F, Salvatore G, Di Benedetto M, De Rosa G, Patrignani P: Expression of COX-2, mPGE-synthase1, MDR-1 (P-gp), and Bcl-xL: a molecular pathway of $\mathrm{H}$ pylori-related gastric carcinogenesis. J Pathol 2004, 202:305-312.

87. Sun WH, Yu Q Shen H, Ou XL, Cao DZ, Yu T, Oian C, Zhu F, Sun YL, Fu XL, Su H: Roles of Helicobacter pylori infection and cyclooxygenase-2 expression in gastric carcinogenesis. World J Gastroenterol 2004. 10:2809-2813

88. Barry EL, Sansbury LB, Grau MV, Ali IU, Tsang S, Munroe DJ, Ahnen DJ, Sandler RS, Saibil F, Gui J, Bresalier RS, McKeown-Eyssen GE, Burke C, Baron JA: Cyclooxygenase-2 polymorphisms, aspirin treatment, and risk for colorectal adenoma recurrence-data from a randomized clinical trial. Cancer Epidemiol Biomarkers Prev 2009, 18:2726-2733.

89. Song $\mathrm{SH}$, Jong HS, Choi HH, Inoue H, Tanabe T, Kim NK, Bang YJ: Transcriptional silencing of Cyclooxygenase-2 by hyper-methylation of the $5^{\prime} \mathrm{CpG}$ island in human gastric carcinoma cells. Cancer Res 2001, 61:4628-4635.

90. de Maat MF, van de Velde CJ, Umetani N, de Heer P, Putter $\mathrm{H}$, van Hoesel AQ, Meijer GA, van Grieken NC, Kuppen PJ, Bilchik AJ, Tollenaar RA, Hoon DS: Epigenetic silencing of cyclooxygenase-2 affects clinical outcome in gastric cancer. J Clin Oncol 2007, 25:4887-4894.
91. Epplein M, Nomura AM, Wilkens LR, Henderson BE, Kolonel LN: Nonsteroidal antiinflammatory drugs and risk of gastric adenocarcinoma: the multiethnic cohort study. Am J Epidemiol 2009, 170:507-514.

92. Park ES, Do IG, Park CK, Kang WK, Noh JH, Sohn TS, Kim S, Kim MJ, Kim KM: Cyclooxygenase- 2 is an independent prognostic factor in gastric carcinoma patients receiving adjuvant chemotherapy and is not associated with EBV infection. Clin Cancer Res 2009, 15:291-298.

93. Chen W, Wang L, Ke Q, Jin G, Tan Y, Zhou Y, Hu Z, Ma H, Wang J, Hua Z, Ding $W$, Shen J, XU Y, Shen H: The role of IGFBP3 functional polymorphisms in the risk of gastric cancer in a high-risk Chinese population. Eur J Cancer Prev 2008, 17:82-87.

94. Pereira C, Medeiros RM, Dinis-Ribeiro MJ: Cyclooxygenase polymorphisms in gastric and colorectal carcinogenesis: are conclusive results available? Eur J Gastroenterol Hepatol 2009, 21:76-91.

95. Jeng YM, Wang TH, Lu SH, Yuan RH, Hsu HC: Prognostic significance of insulin-like growth factor II mRNA-binding protein 3 expression in gastric adenocarcinoma. Br J Surg 2009, 96:66-73.

96. Tomii K, Tsukuda K, Toyooka S, Dote H, Hanafusa T, Asano H, Naitou M, Doihara H, Kisimoto T, Katayama H, Pass HI, Date H, Shimizu N: Aberrant promoter methylation of insulin-like growth factor binding protein-3 gene in human cancers. Int I Cancer 2007, 120:566-573.

97. Lee DY, Yi HK, Hwang PH, Oh Y: Enhanced expression of insulin-like growth factor binding protein-3 sensitizes the growth inhibitory effect of anticancer drugs in gastric cancer cells. Biochem Biophys Res Commun 2002, 294:480-486

98. Garcia-Manero G: Demethylating agents in myeloid malignancies. Curr Opin Oncol 2008, 20:705-710.

doi:10.1186/1750-9378-5-27

Cite this article as: Ryan et al.: Epstein-Barr virus-specific methylation of human genes in gastric cancer cells. Infectious Agents and Cancer 2010 5:27.

\section{Submit your next manuscript to BioMed Central and take full advantage of:}

- Convenient online submission

- Thorough peer review

- No space constraints or color figure charges

- Immediate publication on acceptance

- Inclusion in PubMed, CAS, Scopus and Google Scholar

- Research which is freely available for redistribution

Submit your manuscript at www.biomedcentral.com/submit
Ciomed Central 